\title{
Defective Motor Behavior and Neural Gene Expression in RII $\beta$ - Protein Kinase A Mutant Mice
}

\author{
Eugene P. Brandon, ${ }^{1}$ Sheree F. Logue, ${ }^{4}$ Monique R. Adams, ${ }^{1}$ Ming Qi, ${ }^{1}$ Sean P. Sullivan, ${ }^{1}$ \\ Alvin M. Matsumoto, ${ }^{2}$ Daniel M. Dorsa, ${ }^{1,3}$ Jeanne M. Wehner, ${ }^{4}$ G. Stanley McKnight, ${ }^{1}$ and Rejean L. Idzerda ${ }^{1}$ \\ Departments of ${ }^{1}$ Pharmacology, ${ }^{2}$ Medicine and the Geriatric Research Education and Clinical Center of the Veterans \\ Affairs Puget Sound Health Care System, and ${ }^{3}$ Psychiatry and Behavioral Science, School of Medicine, University of \\ Washington, Seattle, Washington 98195, and 4/nstitute for Behavioral Genetics, University of Colorado, Boulder, \\ Colorado 80309
}

\begin{abstract}
Motor behavior is modulated by dopamine-responsive neurons in the striatum, where dopaminergic signaling uses G-proteincoupled pathways, including those that result in the activation of cAMP-dependent protein kinase (PKA). The RII $\beta$ isoform of PKA is highly enriched in the striatum, and targeted disruption of the RII $\beta$ gene in mice leads to a dramatic reduction in total PKA activity in this region. Although the mutant mice show typical locomotor responses after acute administration of dopaminergic drugs, they display abnormalities in two experience-dependent locomotor behaviors: training on the
\end{abstract}

The basal ganglia modulate motor output from the CNS and have been implicated in several movement disorders, including Parkinson's disease, Huntington's disease, and tardive dyskinesia (Albin et al., 1989). The nigrostriatal dopaminergic projection, which degenerates in Parkinson's disease, plays a critical role in the modulation of basal ganglia function in humans. Similarly, dopaminergic activity in the striatum modulates motor functions in rodents (Gage et al., 1983; Walsh and Wagner, 1992; Emerich et al., 1993; Zhou and Palmiter, 1995).

The psychomotor stimulants, cocaine and amphetamine, are believed to exert their locomotor activating properties primarily by increasing dopaminergic neurotransmission in the striatum. Lesions of the mesostriatal dopaminergic projection abolish amphetamine-enhanced locomotion in rodents (Creese and Iversen, 1975; Koob et al., 1981). Both cocaine and amphetamine increase synaptic dopamine levels by affecting dopamine transporter function (Groves and Rebec, 1976; McMillen, 1983; Sulzer et al., 1995; Giros et al., 1996). A sensitization phenomenon occurs with repeated amphetamine administration, whereby each sequential administration of drug results in an incrementally greater physiological response (Robinson and Becker, 1986; Kalivas and Stewart, 1991). Sensitization requires activation of D1and D2-like dopamine receptors (Ujike et al., 1989; Vezina and

Received Jan. 8, 1998; revised Feb. 27, 1998; accepted Feb. 27, 1998.

This research was supported by National Institutes of Health Grant DA-10156 (J.M.W.), Research Scientist Development Award AA-00141 (S.F.L.), Training Grant GM-07108 (E.P.B.), and GM-32875 (G.S.M.). We thank Kirstin Gerhold, Kelly Millett, and Thong Su for excellent technical assistance. We also thank Dr. James Douglass for providing the dynorphin cDNA, Dr. Alan Unis for dopamine receptor analysis, and Dr. Carol Quaife for assistance with photomicroscopy. We are grateful to Drs. Richard Palmiter and Eric Kandel for insightful comments on this manuscript.

Correspondence should be addressed to Dr. G. Stanley McKnight, Department of Pharmacology, University of Washington, Box 357750, Seattle, WA 98195.

Copyright (C) 1998 Society for Neuroscience $0270-6474 / 98 / 183639-11 \$ 05.00 / 0$ rotarod task and locomotor sensitization to amphetamine. In addition, amphetamine induction of fos is absent, and the basal expression of dynorphin mRNA is reduced in the striatum. These results demonstrate that motor learning and the regulation of neuronal gene expression require RII $\beta$ PKA, whereas the acute locomotor effects of dopaminergic drugs are relatively unaffected by this PKA deficiency.

Key words: cAMP-dependent protein kinase; PKA; knockout; mouse; striatum; dopamine; amphetamine; locomotion; rotarod; sensitization; fos; dynorphin
Stewart, 1989) and depends on protein synthesis (Karler et al., 1993). Recently, mice have been developed that have alterations in their dopaminergic function. Mice genetically deficient in dopamine show extreme hypoactivity unless rescued with L-dopa (Zhou and Palmiter, 1995). Conversely, mice lacking the dopamine transporter are hyperactive and are unresponsive to the locomotor-activating effects of amphetamine and cocaine (Giros et al., 1996). Mice lacking the various dopamine receptors (D1R, D2R, D3R, D4R) exhibit a range of locomotor defects (Drago et al., 1994; Xu et al., 1994a,b; Baik et al., 1995; Accili et al., 1996; Rubinstein et al., 1997). Collectively, these mutants demonstrate a critical role for dopaminergic signaling in the regulation of motor output. In some cases, changes in the expression of striatal peptides that are believed to modulate motor output (such as dynorphin, substance P, and enkephalin) have been correlated with the motor defects.

In the striatum, distinct populations of efferent medium spiny neurons express D1- and D2-like receptors (Gerfen et al., 1990; Hersch et al., 1995), although recent data suggest the possibility that some neurons express both receptor subtypes (Surmeier et al., 1996). D1-like receptors generally are thought to act via $\mathrm{G}_{\mathrm{s}}$-type proteins to increase the production of cAMP by adenylyl cyclase and thus activate the cAMP-dependent protein kinase, PKA. Conversely, D2-like receptors are $\mathrm{G}_{\mathrm{i}} / \mathrm{G}_{\mathrm{o}}$-coupled and can inhibit cyclase activity, activate an inward rectifying $\mathrm{K}^{+}$channel, or inhibit $\mathrm{Ca}^{2+}$ channels (Stoof and Kebabian, 1981; Greif et al., 1995; Surmeier et al., 1995). Thus, PKA likely serves as one of the important effector molecules in dopamine responsive neurons.

In the mouse there are six PKA subunit isoform genes. Each PKA holoenzyme consists of two homodimeric regulatory (R) subunits and two catalytic (C) subunits; the type of holoenzyme is defined by its regulatory subunits (i.e., RII $\beta$-PKA is $\mathrm{RII} \beta_{2} \mathrm{C}_{2}$ ). In situ hybridization analysis suggests that, of the regulatory sub- 
units ( $\mathrm{RI} \alpha, \operatorname{RI} \beta, \mathrm{RII} \alpha$, and $\mathrm{RII} \beta), \operatorname{RII} \beta$ has the highest expression in the striatal complex, including the caudoputamen, nucleus accumbens, and islands of Calleja (Cadd and McKnight, 1989). To distinguish which effects of dopamine depend on RII $\beta$-PKA and which are likely to rely on other G-protein-mediated signaling pathways, we have created mice with a targeted disruption of the predominant striatal regulatory subunit, $\operatorname{RII} \beta$. The $\operatorname{RII} \beta$ knock-out mice are severely deficient in striatal PKA activity and exhibit changes in gene expression and locomotor behavior.

\section{MATERIALS AND METHODS}

Gene disruption and genotyping. The disruption of the RII $\beta$ gene in embryonic stem (ES) cells has been described (Brandon et al., 1995a). Chimeras were bred to obtain heterozygotes, which were interbred to produce homozygous mutant and wild-type littermates. All experiments used these F1 (50\% C57BL/6 and 50\% 129SvJ) mice or the offspring generated from breeding each genotype, and they were age- and gendermatched. ES cells and mice were genotyped by genomic Southern blot and/or PCR analysis, using standard techniques.

Northern blot analysis. Tissue was homogenized in $8 \mathrm{~m}$ guanidine hydrochloride and $25 \mathrm{~mm}$ sodium acetate, and RNA was precipitated with $0.6 \mathrm{vol}$ of ethanol. After centrifugation, the RNA pellet was resuspended in $8 \mathrm{M}$ guanidine hydrochloride and $25 \mathrm{~mm}$ sodium acetate, extracted with a 50:50 mixture of phenol and chloroform, and then reprecipitated with 0.6 vol of ethanol. Northern blot analysis was performed essentially as described (Mosley et al., 1989), using a ${ }^{32} \mathrm{P}-$ riboprobe synthesized from a 357 base pair cDNA fragment that encodes a C-terminal portion of RII $\beta$.

Western blot analysis and kinase assays. Protein was prepared from various brain regions by Dounce homogenization in PBS containing (in mM) 250 sucrose, 1 EGTA, 4 EDTA, 4 DTT, and 4-(2-aminoethyl)benzenesulfonyl fluoride hydrochloride (AEBSF) plus $0.5 \%$ Triton $\mathrm{X}-100,2 \mu \mathrm{g} / \mathrm{ml}$ leupeptin, $3 \mu \mathrm{g} / \mathrm{ml}$ aprotinin, and $0.2 \mathrm{mg} / \mathrm{ml}$ soybean trypsin inhibitor, followed by sonication and centrifugation for $10 \mathrm{~min}$ at $12,000 \times g$ at $2^{\circ} \mathrm{C}$. Supernatant proteins $(40 \mu \mathrm{g} /$ lane) were resolved by $10 \%$ SDS-PAGE and transferred onto nitrocellulose (Schleicher \& Schuell, Keene, NH). Blots were pretreated overnight at room temperature in blocking buffer (5\% BSA, $0.2 \%$ Tween-20, and $0.01 \%$ sodium azide) and probed with antisera to murine PKA subunits as described (Cummings et al., 1996). Kinase activity in the tissue supernatants was assayed as described (Clegg et al., 1987), using Kemptide as a substrate in the presence or absence of $5 \mu \mathrm{M}$ cAMP, each in the presence or absence of $40 \mu \mathrm{g} / \mathrm{ml}$ PKI peptide inhibitor. Three mice of each genotype were assayed, and the results were averaged. Activity is reported as units (pmol per min) per milligram of protein after nonspecific kinase activity is subtracted (the kinase activity not inhibited by PKI). The halfmaximal activation constants $\left(K_{\mathrm{a}}\right)$ were determined in mutant and wildtype striatum as described (Cadd et al., 1990). Striata from three mice of each genotype were pooled and then assayed in triplicate. The high concentration of PKA in the homogenates exceeds the cAMP concentration that should yield half-maximal activation, making an accurate $K_{\mathrm{a}}$ comparison difficult with cAMP, so a cyclic nucleotide with lower affinity, cIMP, was used instead.

Rotarod performance. The rotarod apparatus (Ugo Basile, Varese, Italy) was used in two different acceleration modes, gradually increasing either from 4 to $30 \mathrm{rpm}$ ("slow" speed) or from 5 to $35 \mathrm{rpm}$ ("fast" speed) over the course of $5 \mathrm{~min}$. Mice were placed on the apparatus, and rotation was initiated. Latency to fall was recorded automatically. Trials were given within the last $4 \mathrm{hr}$ of the light phase of the $12 \mathrm{hr}$ light/dark cycle, 10-25 min apart. Ten trials were given on the first day and four on the second. Mice that stayed on the rotarod for $>300 \mathrm{sec}$ were considered complete responders; their latencies were recorded as $300 \mathrm{sec}$. At the slow speed, 6 of 17 wild-type mice reached this criterion, and no mutants did. At the fast speed only 1 of 11 mutants reached this criterion, and none of the wild types did.

Locomotor activity. Mice were placed in the darkened testing room 30 min before testing. Locomotor activity was assessed in an automated open field arena illuminated by a bright white light. The number of infrared photobeam interruptions in each perpendicular axis was recorded and totalled for each session. The arena was cleaned with $75 \%$ ethanol after each trial. For drug studies, mice were injected intraperitoneally with drug or saline $15 \mathrm{~min}$ before testing and placed in a holding cage until testing. Amphetamine and cocaine test sessions were $15 \mathrm{~min}$; those for quinpirole and SKF38393 were $30 \mathrm{~min}$.

Paw print assay. Age-matched $(\sim 15$ weeks $)$ male mice were tested during the last $6 \mathrm{hr}$ of the light phase of the light/dark cycle. The back paws of each mouse were dipped into ink, and the animals were placed at the entry of a dark tunnel $(9.2 \times 6.3 \times 35.5 \mathrm{~cm})$. Footprints were recorded on a clean sheet of white paper placed on the floor of the tunnel. Stride length was determined by measuring the distance between each step on the same side of the body. For each animal, the six strides closest to the center of the paper were measured. This excluded strides at the beginning and end of the tunnel where the animal was initiating and terminating movement. Average stride length was calculated. The length of the shortest of these strides was subtracted from the length of the longest to determine the range in stride length for each subject.

Grooming. Mice were housed individually for $24 \mathrm{hr}$ before the experiment. Trials were given within the last $4 \mathrm{hr}$ of the light phase of the light/dark cycle. Mice were injected intraperitoneally, and then food and water were removed from the cage. Each mouse was observed once per minute, and its activity was recorded (activities included locomotion, grooming, nibbling on bedding or feces, digging in bedding, and stationary/sleeping). The proportion of each type of activity observed from 15 to $115 \mathrm{~min}$ after injection was determined and analyzed.

Determination of brain amphetamine levels. Animals were injected intraperitoneally with D-amphetamine $(5 \mathrm{mg} / \mathrm{kg})$ and killed 15 min later. Brains were removed, weighed, and homogenized in ice-cold $0.05 \mathrm{M}$ sodium borate, $\mathrm{pH} 10$; methamphetamine was added as an internal standard. Homogenates were centrifuged at $10,000 \times g$ at $10^{\circ} \mathrm{C}$ for 10 min. Drugs were extracted from the supernatants with an equal volume of ethyl acetate, followed by centrifugation at $1000 \times g$ at $10^{\circ} \mathrm{C}$ for 10 $\mathrm{min}$. The extract was dried under a stream of nitrogen and resuspended in a 50:50 mixture of acetonitrile/1-chlorobutane. Samples $(1 \mu \mathrm{l})$ were analyzed by gas chromatography in a Hewlett-Packard 5890 with an HP-5 column $(25 \mathrm{~m} \times 0.32 \mathrm{~mm})$ and a nitrogen/phosphorous detector. Split (50:1) $1 \mu$ l injections were analyzed. The injection port was heated to $250^{\circ} \mathrm{C}$, and samples were chromatographed at an initial temperature of $150^{\circ} \mathrm{C}$ and ramped at $10^{\circ} \mathrm{C}$ per minute to $260^{\circ} \mathrm{C}$ and held for $5 \mathrm{~min}$. The detector was maintained at $275^{\circ} \mathrm{C}$. The flow rate was $1.2 \mathrm{ml} / \mathrm{min}$ helium. Data were collected and analyzed on an HP3396 integrator, and areas under the curve were determined by using an amphetamine standard curve (5-95 ng/ $\mu \mathrm{l} ; r=0.99)$; recoveries were calculated on the basis of the internal standard. Data are reported as micrograms of amphetamine per gram of brain wet weight.

Hormone analyses. Glucocorticoid levels were assayed in blood plasma, using a rat corticosterone- ${ }^{3} \mathrm{H}$ kit (ICN Biomedicals, Cleveland, $\mathrm{OH}$ ). Dopamine was assayed in striatal homogenates by HPLC with electrochemical detection as described (Liebmann and Matsumoto, 1990).

Dopamine transporter assay. The striatum was dissected and homogenized, and synaptosomes were prepared as described (Grady et al., 1992) with modifications. After centrifugation at $12,000 \times \mathrm{g}$, the pellet was resuspended in buffer containing (in $\mathrm{mM}$ ) $128 \mathrm{NaCl}, 2.4 \mathrm{KCl}, 3.2 \mathrm{CaCl}_{2}$, $1.2 \mathrm{KH}_{2} \mathrm{PO}_{4}, 1.2 \mathrm{MgSO}_{4}, 25$ HEPES, $\mathrm{pH}$ 7.4, 10 dextrose, 1 ascorbate, and 0.01 pargyline. Aliquots were incubated with or without various concentrations of D-amphetamine $\left(10^{-9}\right.$ to $\left.10^{-3} \mathrm{M}\right)$, along with $5 \mu \mathrm{Ci}$ of ${ }^{3} \mathrm{H}$-dopamine $(0.1 \mu \mathrm{M}$; specific activity $=48 \mathrm{Ci} / \mathrm{mmol})$. The assay was terminated by the addition of ice-cold buffer and then filtered over GF/C filters with washing. Radioactivity was determined in a scintillation counter, and the results were calculated per milligram of protein.

Receptor binding. Dopamine D1 and D2 receptor binding was performed as described (Bouthenet et al., 1991) with modifications. D1 receptors were assayed with ${ }^{125}$ I-labeled SCH23982 (DuPont) and D2 receptors were labeled with ${ }^{125} \mathrm{I}$-sulpiride (Amersham, Arlington Heights, IL). Sections were incubated for $45 \mathrm{~min}$ at room temperature with $250 \mu \mathrm{l}$ of (in mM) 50 Tris-HCl buffer, $\mathrm{pH} 7.4,120 \mathrm{NaCl}, 5 \mathrm{KCl}, 1$ $\mathrm{CaCl}_{2}, 5.7$ ascorbic acid, and 0.018 -hydroxyquinoline plus $3 \mathrm{~nm}\left[{ }^{125} \mathrm{I}\right]$ drug. Then the slides were washed in fresh buffer, dipped in deionized water, and dried promptly. Nonspecific binding was defined as residual binding in the presence of $3 \mathrm{~mm}$ fluphenazine. Labeled slides were stored overnight at $4^{\circ} \mathrm{C}$ in the presence of a desiccant and then apposed for 30 min to Hyperfilm $\beta$-Max, along with plastic standards containing known concentrations of ${ }^{125} \mathrm{I}$ (Amersham). Similar results were obtained in two independent experiments.

In situ hybridization. In situ hybridization was performed as described (Ward and Dorsa, 1996), using ${ }^{35} \mathrm{~S}$-labeled antisense riboprobes for dynorphin, $c$-fos, or RII $\beta$. The specificity of the probes was established by hybridization with labeled sense probes. Brain sections from different 
A

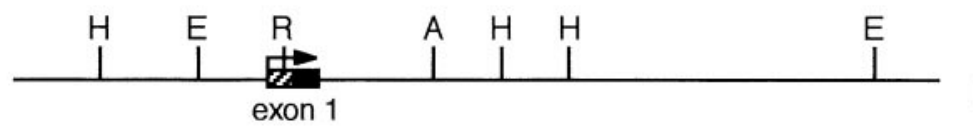

normal

RII $\beta$ gene

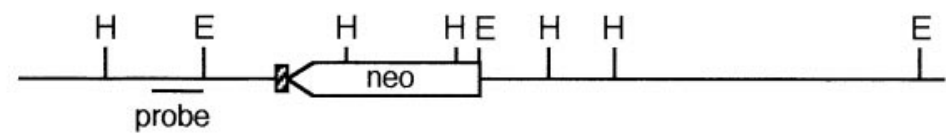

disrupted allele $1 \mathrm{~kb}$

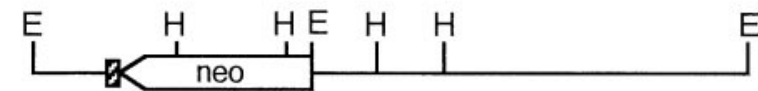

targeting vector
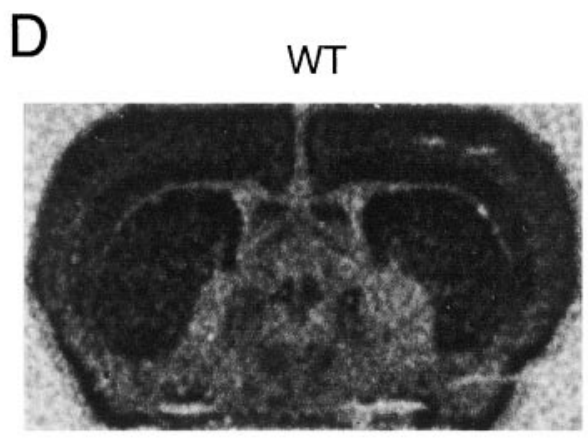

RII $\beta$ KO

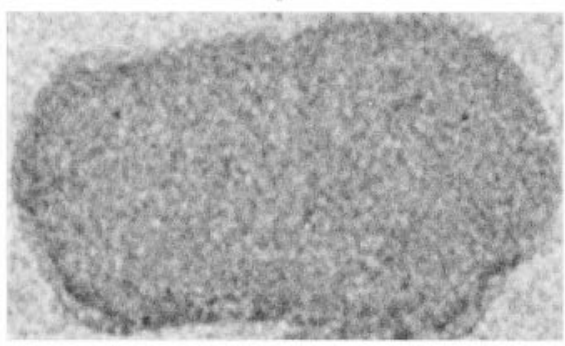

Figure 1. Targeted disruption of RII $\beta$. A, Genomic locus, targeting vector, and predicted structure of targeted locus. The targeting vector replaces the coding region of exon 1 of the RII $\beta$ gene with a neomycin resistance cassette (neo). Restriction enzyme sites shown include the following: $A$, AatII; $E$, EcoRI; H, HindIII; R, RsrI. The probe fragment used to identify disrupted alleles in ES cells and mice is shown. $B$, Genomic Southern blot of tail DNA from offspring of a cross of heterozygotes. DNA was digested with HindIII and probed with the fragment shown in $A$. The wild-type allele yields a 4.7 $\mathrm{kb}$ band, and the disrupted allele yields a $3.0 \mathrm{~kb}$ band. Genotypes are indicated above each lane: wild type $(+/+)$, heterozygous $(+/-)$, and homozygous mutant $(-/-)$. $C$, Northern blot of brain total RNA $(10 \mu \mathrm{g})$ from wild-type $(+/+)$ and homozygous mutant $(-/-)$ mice, probed with a 350 bp riboprobe specific for RII $\beta$. The migration of RII $\beta$ mRNA is indicated. $D$, In situ hybridization of wild-type $(W T)$ and homozygous mutant $(R I I \beta k o)$ brain slices, using the RII $\beta$-specific riboprobe. Expression is high in the cortex and striatum and is low in the globus pallidus.

groups were matched anatomically by bright-field microscopy. For quantitative analysis autoradiograms were analyzed with a microcomputerbased image analysis system (MCID, Imaging Research, St. Catherine's, Ontario, Canada) to determine OD, and the dynorphin image was colorized for illustration. For both $c$-fos and dynorphin, samples of the size indicated in Figure $7 A$ were taken from coronal slices between the genu of the corpus collosum and the decussation of the anterior commissure. An average value for each region was determined for each mouse ( $\sim 20$ samples per region per mouse); the averages shown in Figures $6 B$ and $7 B$ represent averages of the values determined for each mouse. For the data shown in Figure $7 B$, values from the septum of each slice were subtracted before averaging; this region showed no specific signal over cells on emulsion-coated slides and thus was considered nonspecific background.

\section{RESULTS}

\section{Mice lacking RII $\beta$ are fertile and long-lived}

Gene targeting was performed by standard techniques (Capecchi, 1989). The mutation eliminated the entire coding region of the first exon of the RII $\beta$ gene, including the translation start site (Fig. 1A). Germ line-competent chimeras were bred to produce heterozygous mice. Wild-type, heterozygous, and homozygous mutant offspring from crosses of heterozygotes (Fig. 1B) were produced at the predicted Mendelian frequency, indicating that no embryonic lethality is associated with the mutation. Homozygous mutant mice expressed no detectable mRNA for RII $\beta$, as determined by Northern blot analysis (Fig. $1 C$ ) and in situ analysis (Fig. $1 D$ ). Figure $1 D$ also illustrates the high expression of $\operatorname{RII} \beta$ mRNA in the striatum of normal mice.

$\operatorname{RII} \beta$ is normally present at high levels in adipose tissue, brain, and hematopoietic tissues (fetal liver and bone marrow). RII $\beta$ also is expressed in reproductive cells, where it is regulated by hormones that activate PKA, suggesting an important reproductive function (Jahnsen et al., 1986; Oyen et al., 1988). However, RII $\beta$ mutant mice exhibited normal fertility, as evidenced by both pregnancy rate and litter size. The mice were morphologically normal in all tissues examined except the adipose, where they showed a reduction in fat accumulation (Cummings et al., 1996).

\section{$R I I \beta$ is the major isoform of PKA in the striatum}

Although both in situ analysis of RII $\beta$ mRNA expression (Cadd and McKnight, 1989) and immunohistochemical analysis of RII $\beta$ protein expression (Ludvig et al., 1990; Glantz et al., 1992) have been performed on mouse brain, the relative contribution of RII $\beta$ holoenzyme to the total PKA complement in any given region of the brain has not been determined previously. Western blots comparing equal amounts of protein from various regions of the mouse brain showed that $\operatorname{RII} \beta$ expression is highest in the striatum, lower in other brain regions, and nearly undetectable in the cerebellum (Fig. 2A). Kinase assays were performed to determine the amount of cAMP-dependent activity remaining in various brain regions of $\mathrm{RII} \beta$ knock-out mice (Fig. $2 C$ ). In the whole brain, total cAMP-stimulated activity was reduced by $\sim 50 \%$, as compared with wild-type mice, similar to the reduction observed in isolated cortex. A modest decline was detected in cerebellum, whereas a $75 \%$ reduction in activity was evident in the striatum. Thus, RII $\beta$-PKA comprises the majority of PKA in the normal mouse striatum.

Previous studies suggested that loss of RII $\beta$ might lead to compensatory changes in other PKA subunits. A compensatory increase in $\mathrm{RI} \alpha$ has been detected in multiple systems in which the PKA system has been perturbed (Amieux et al., 1997), in- 

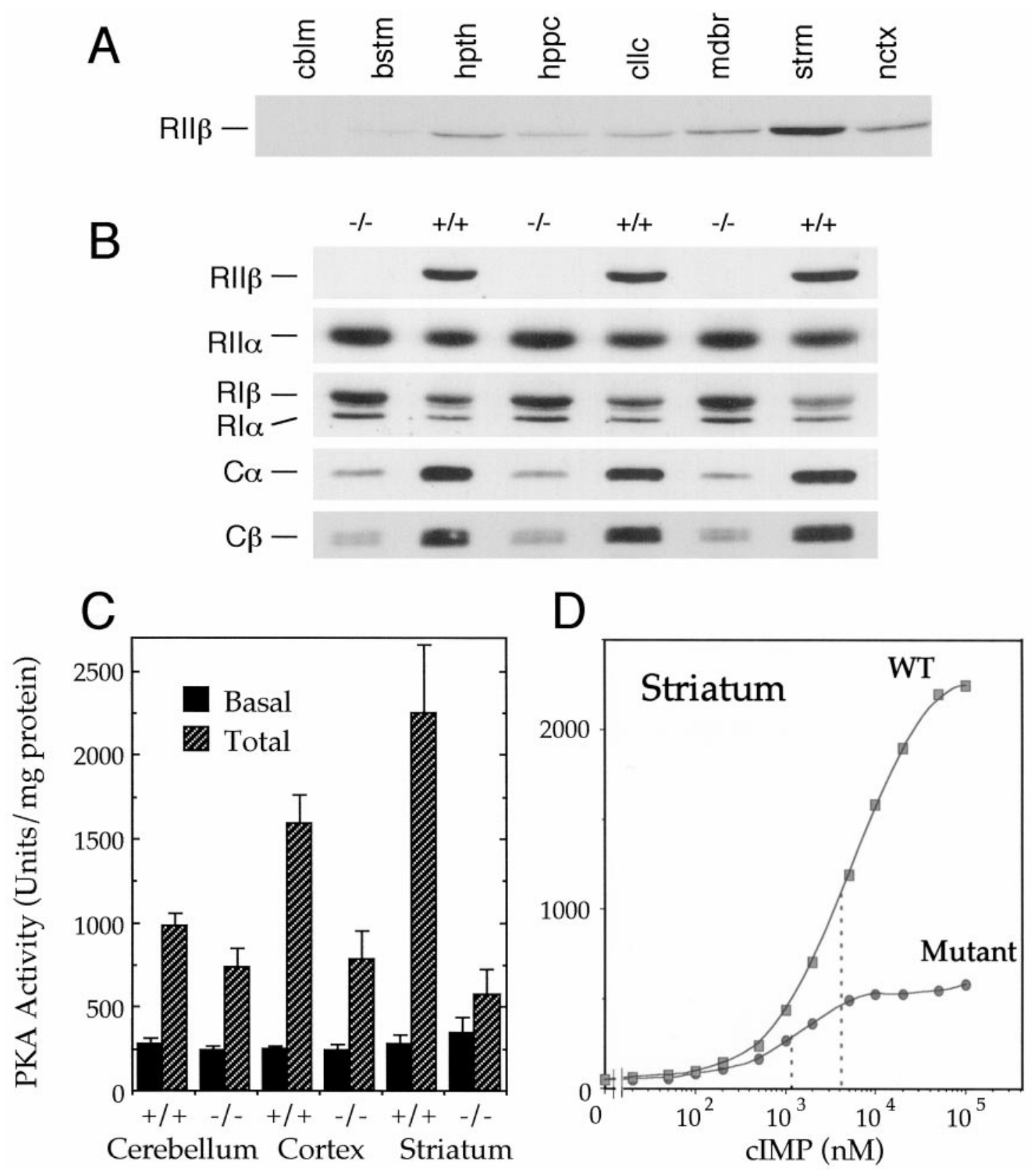

Figure 2. RII $\beta$ is the major PKA isoform in the striatum. $A$, Western blot of several regions of wild-type mouse brain probed with RII $\beta$-specific antiserum. Lanes (from left to right), cblm, cerebellum; bstm, brainstem; hpth, hypothalamus; hppc, hippocampus; cllc, colliculi; $m d b r$, midbrain; strm, striatum; $n c t x$, neocortex. $B$, Western blot analysis of PKA subunit isoform levels in striatum, using homogenates from three wild-type $(+/+)$ and three RII $\beta$ knock-out $(-/-)$ mice. Blots were probed with antibodies to the indicated PKA subunits. $C$, Kinase assay with homogenates of the indicated brain regions from wild-type $(+/+)$ and mutant $(-/-)$ mice. Phosphorylation of the PKA substrate Kemptide was assayed in the presence (Total) or absence (Basal) of $5 \mu \mathrm{M}$ cAMP. Error bars represent SEM. D, PKA activation curves with striatal homogenates from wild-type (wt) and RII $\beta^{-/-}(m u t a n t)$ mice. Half-maximal activation (dotted lines) was achieved at $\sim 4 \mu \mathrm{M}$ cIMP in wild-type mice and $1 \mu \mathrm{M}$ cIMP in mutants. cIMP was used instead of cAMP because of its lower affinity for PKA R subunits (see Materials and Methods).

cluding the brown adipose tissue of the RII $\beta$ mutants (Cummings et al., 1996) and the brain of RI $\beta$ null mutants (Brandon et al., $1995 \mathrm{~b})$. In striatum from RII $\beta$ mutants, elevated levels of both $\mathrm{RI} \alpha$ and $\mathrm{RI} \beta$ were found, with a smaller increase in the $\mathrm{RII} \alpha$ isoform level (Fig. 2B). However, the increases in these $\mathrm{R}$ subunits did not compensate fully for the loss of RII $\beta$, leaving the unbound $\mathrm{C}$ subunits susceptible to proteolysis. Thus, the catalytic subunits of PKA $(\mathrm{C} \alpha$ and $\mathrm{C} \beta$ ) were reduced dramatically in the mutant striatum, as predicted by the kinase assays. All of these changes in subunit levels are likely to result from altered protein stability, because mRNA levels for the subunits are unchanged in the RII $\beta$ mutants (data not shown) (Amieux et al., 1997).

The loss of $\operatorname{RII} \beta$ and increases in $\mathrm{RI} \alpha$ and $\mathrm{RI} \beta$ indicate a shift in isoform prevalence from type II to type I PKA in mutant striatum. A comparison of PKA activation curves (Fig. 2D) demonstrated that the PKA remaining in mutant striatum was activated at an approximately fourfold lower cyclic nucleotide concentration than in wild type. This is consistent with the increased sensitivity of type I kinase to activation, as compared with type II (Cummings et al., 1996). 


\section{RII $\beta$ knock-out mice are impaired in the rotarod task}

Because PKA is one of the potential downstream effectors of dopamine receptor activation, we sought to determine whether motor output was disrupted in these mice. We used the accelerating rotarod task to measure the mouse's ability to coordinate movement under challenging conditions (Dunham and Miya, 1957). The task measures how long a mouse can stay on a rotating horizontal rod as its speed of rotation is increased. Performance of this task involves both the cerebellum and the striatum and has been shown both to require dopamine and to evoke its release in the striatum (Bertolucci et al., 1990; Emerich et al., 1993; Lalonde et al., 1995). Mice were placed on the rod; rotation was initiated and then accelerated from 5 to $35 \mathrm{rpm}$ over the course of $5 \mathrm{~min}$. As shown in Figure $3 A$, wild-type mice have difficulty with the task at first but within a few trials improve their performance significantly. In contrast, RII $\beta$ mutants show some acquisition but never attain the same competence with this task as wild-type mice. We considered the possibility that the RII $\beta$ knock-out mice require a longer consolidation period to learn the rotarod task. This phenotype might be expected if the RII $\beta$-PKA isoform plays a significant role in short-term motor learning, but not in longterm memory formation, i.e., that which might require novel gene expression or protein synthesis (Goelet et al., 1986). Thus, the mice were tested again $1 \mathrm{~d}$ later to determine whether their latencies improved. Only slight improvement by the mutants was seen on the second day (Fig. $3 A$ ). With further testing, mice of both genotypes maintained performances similar to those observed on day 2 , with the latencies for mutants remaining consistently below those of wild-type mice (data not shown). In a second set of experiments, mice were tested at a less challenging rate of acceleration to determine whether this might facilitate their acquisition of this task. The wild-type mice showed a more rapid acquisition and increased their average latencies at this lower rate, but the RII $\beta$ mutants were still dramatically impaired (Fig. 3B). These data show that the ability to coordinate motor output is disrupted by the absence of RII $\beta$. The defect in motor coordination is specific for the loss of the RII $\beta$ subunit of PKA, because mice lacking the RI $\beta$ subunit isoform showed no such decrement (data not shown).

Poor performance on the rotarod task can result from cerebellar dysfunction, although we considered this to be unlikely in the RII $\beta$ mutants because little if any RII $\beta$ normally is expressed in the cerebellum. To assess cerebellar function, we performed a paw print assay in which the hind paws of the mice were inked, allowing their tracks to be recorded as they walked through a tunnel. Typical tracks from wild-type and mutant mice are shown in Figure $4 A$, revealing no obvious differences. Analyses of mean stride length and mean range in stride length also showed no abnormalities in the mutants (Fig. 4B). A standard open-field test in a novel setting was used to examine spontaneous horizontal locomotor activity because this has been shown to be greater in mice with vestibular deficits. No difference in photobeam breaks was observed between the mutant and wild-type mice (Fig. $4 C$ ). These data demonstrate that the absence of RII $\beta$ does not produce cerebellar defects manifested as balance or locomotor abnormalities.

\section{RII $\beta$ knock-out mice exhibit typical acute behavioral responses to dopaminergic agents but increased sensitization to chronic amphetamine}

Acute administration of an indirect dopaminergic agonist (amphetamine or cocaine) causes increased horizontal locomotion in
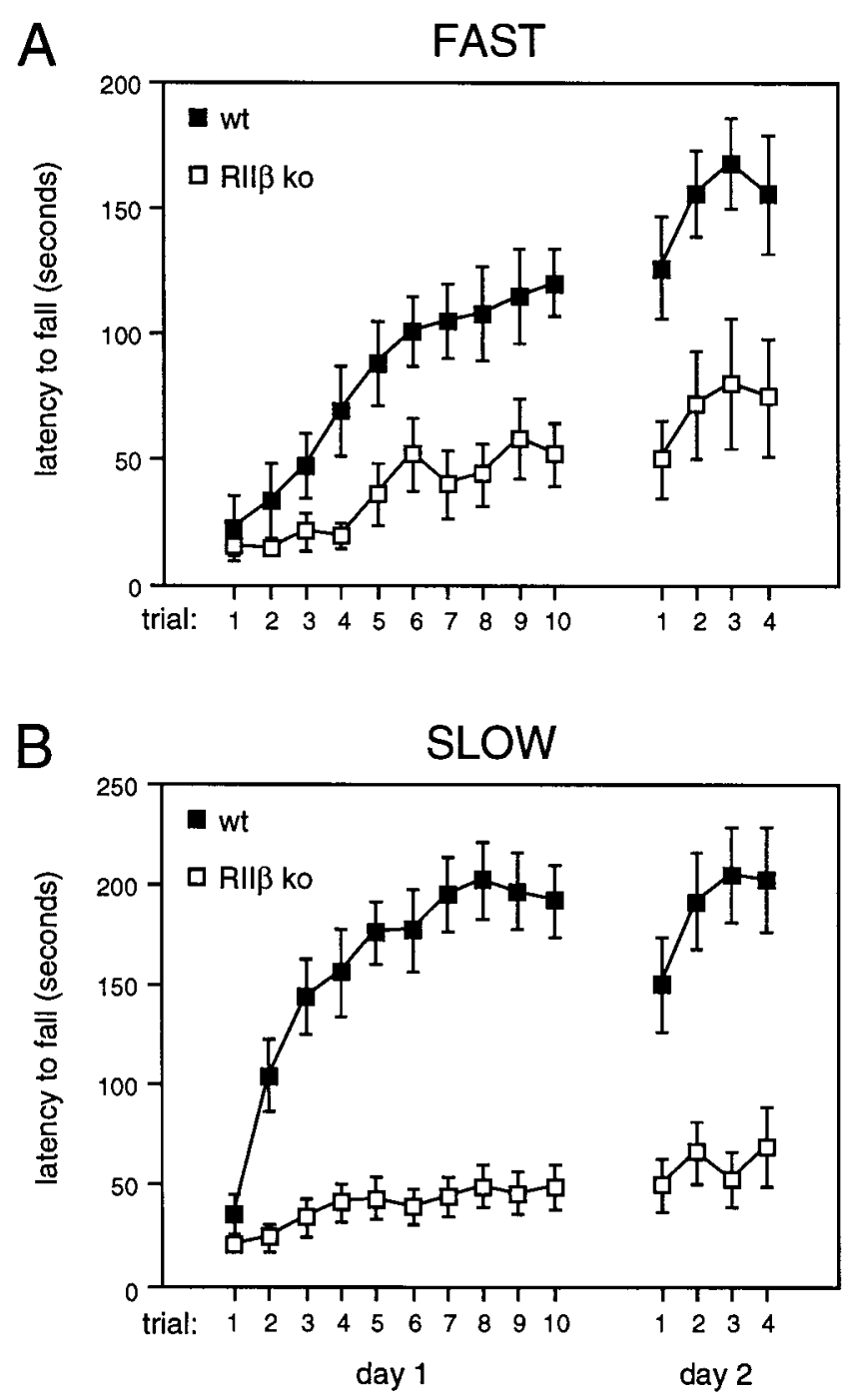

Figure 3. Impaired performance of RII $\beta$ knock-out mice on the rotarod task. $A$, RII $\beta^{-1-}$ (open squares; $n=11$ ) and wild-type control mice (closed squares; $n=13$ ) were tested for their ability to stay on the accelerating rotarod. Ten trials were conducted on the first day and four on the second day (error bars represent SEM). ANOVA for repeated measures revealed a significant effect of trials $1-10$ on day 1 in both wild-type $\left(F_{(9,108)}=7.62\right.$; $p<0.001)$ and $\operatorname{RII} \beta$ knock-out mice $\left(F_{(9,90)}=5.11 ; p<0.001\right)$ as well as a significant effect of genotype $\left(F_{(1,22)}=14.07, p<0.002\right.$ on day $1 ; F_{(1,22)}$ $=10.24, p<0.005$ on day 2). $B$, When tested at a lower rate of acceleration, $\mathrm{RII} \beta^{-/-}$(open squares; $n=18$ ) mice were impaired significantly, as compared with wild-type control mice (closed squares; $n=17$; $F_{(1,33)}=60.76, p<0.001$ on day $1 ; F_{(1,33)}=26.90, p<0.001$ on day 2$)$.

mice. Figure $5 A$ demonstrates that a high dose of amphetamine or cocaine evoked acute locomotor responses that were similar in wild-type and RII $\beta$ mutant mice. Under some treatment regimens, repeated administration of amphetamine produces a sensitization phenomenon whereby each sequential administration of drug results in a greater response than that seen previously (Robinson and Becker, 1986; Kalivas and Stewart, 1991). We found that, whereas the wild-type mice displayed modest sensitization to amphetamine, the RII $\beta$ mutant mice displayed significantly greater sensitization, particularly at low doses. Figure $5 B$ depicts the responses to two different doses of amphetamine administered for $5 \mathrm{~d}$.

One explanation for the increased responsiveness to amphet- 

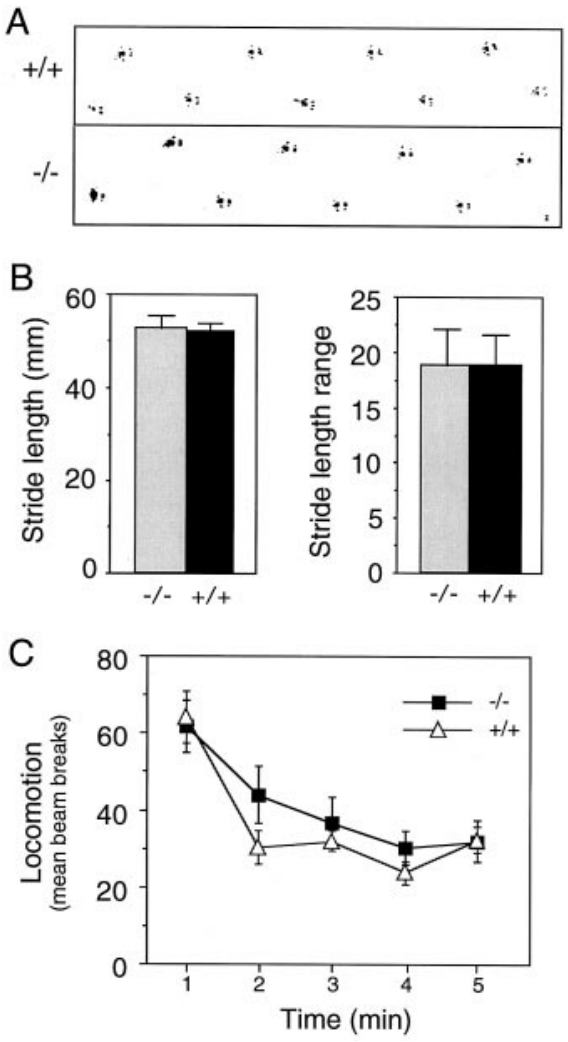

Figure 4. RII $\beta$ mutants have no obvious cerebellar or locomotor behavioral defects. $A$, Hind paw footprints were recorded, and representative prints of a wild-type $(+/+)$ and RII $\beta$ mutant $(-/-)$ mouse are shown. $B$, Mean stride length and mean range in stride length in the paw print assay were similar in both wild-type $(+/+; n=10)$ and RII $\beta$ mutant $(-/-; n=$ 9) mice. $C$, Locomotor activity in response to a novel environment was recorded in an open-field arena, and similar responses were observed in wild-type $(+/+; n=10)$ and RII $\beta$ mutant $(-/-; n=9)$ mice. Error bars represent SEM in all panels.

amine of the RII $\beta$ knock-out mice could be altered pharmacokinetics (Camp et al., 1994). Therefore, amphetamine levels in the brains of mutant and wild-type mice 15 min after drug (5.0 $\mathrm{mg} / \mathrm{kg}$ ) administration were analyzed by gas chromatography. The mice were not significantly different $(6.85 \pm 1.09 \mu \mathrm{g} / \mathrm{gm}$ for 12 mutants and $5.99 \pm 1.03 \mu \mathrm{g} / \mathrm{gm}$ for 9 wild-type mice; $p=0.55)$.

Hyperresponsiveness to amphetamine also has been seen in rodents with elevated glucocorticoid levels (Pauly et al., 1993). When stressed by amphetamine administration $(5.0 \mathrm{mg} / \mathrm{kg}), \operatorname{RII} \beta$ mutant mice actually have lower plasma corticosterone levels than wild-type control mice (291.4 $\pm 41.2 \mathrm{ng} / \mathrm{ml}$ for wild-type mice, $n=15 ; 173.2 \pm 36.0 \mathrm{ng} / \mathrm{ml}$ for RII $\beta$ mutants, $n=14$; all at $15 \mathrm{~min}$ after drug administration), ruling out high glucocorticoids as an explanation for the increased responsiveness of the mutants.

To investigate whether the loss of RII $\beta$ impacts both D 2 and D1 dopaminergic pathways, we determined the locomotor responsiveness of mutant mice to specific agonists. The D1R agonist SKF38393 activated horizontal locomotion in both mutant and wild-type control mice at several doses $(8.0 \mathrm{mg} / \mathrm{kg}$ is shown in Fig. 5D). A second D1R-mediated acute behavior also was examined; the D1R agonist SKF81297 increased grooming significantly in both genotypes (Fig. 5C). As observed by other investigators (Picetti et al., 1997), a low dose of the D2/D3R agonist quinpirole suppressed locomotion in wild-type mice; RII $\beta$ mutants responded similarly (Fig. $5 D$ ). Whether this sup- pression is attributable to quinpirole acting on D3 receptors or on presynaptic D2 receptors is a matter of debate at present. These data demonstrate that acute locomotor responses to dopaminergic agonists are normal. Thus, locomotor defects do not provide a simple explanation for the poor rotarod performance of the mutants.

Besides the obvious loss of PKA in the striatum, what other components of the dopaminergic pathways might be altered in the mutant mice? As shown in Table 1, no significant difference in the level of dopamine was found in the striatum. D1-like receptor levels were measured in various regions of the caudoputamen, and although the value for the dorsolateral region is smaller in the knock-out mice, as compared with wild types, this difference did not reach statistical significance $(p=0.07)$. Similarly, the D2-like receptor levels were normal. The function of the dopamine transporter was investigated by measuring dopamine uptake into synaptosomes, and no differences were observed in either basal transporter function or in the inhibition of dopamine uptake by amphetamine.

\section{RII $\beta$-PKA is required for the induction of $c$-fos in the dorsomedial striatum by amphetamine}

To begin to ascertain whether gene regulatory events also might be altered in the RII $\beta$ mutant mice, we examined the ability of amphetamine to induce $c$-fos mRNA in the striatum. The $c$-fos promoter contains a $\mathrm{Ca}^{2+} / \mathrm{CRE}$ element (Sheng et al., 1990), which is responsive to cAMP, and thus expression of $c$-fos provides a reasonable indicator of endogenous PKA-mediated gene induction (Sassone-Corsi et al., 1988).

Basal levels of $c$-fos mRNA were low in the striata of both RII $\beta$ knock-out and wild-type mice. As shown in Figure 6, $1 \mathrm{hr}$ after the administration of amphetamine the wild-type mice exhibited a significant induction of $c$-fos mRNA in the dorsomedial region of the striatum. In striking contrast, the RII $\beta$ mutant mice almost entirely lacked this induction. Induction of $c$-fos in the cortex remained intact. The lack of striatal $c$-fos induction is specific for the $\operatorname{RII} \beta$ mutants because mice lacking the $\operatorname{RI} \beta$ subunit isoform showed normal induction of $c$-fos in this region (data not shown).

\section{Reduced dynorphin mRNA in RII $\beta$ mutants}

Dynorphin, a $\kappa$ opioid receptor agonist that is expressed by striatal neurons, is believed to affect motor function and sensitization to psychostimulants (Thompson et al., 1990; Angulo and McEwen, 1994; Heidbreder et al., 1995). Psychostimulants have been shown to induce dynorphin mRNA in the striatum of the rat (Steiner and Gerfen, 1993; Jaber et al., 1995; Wang et al., 1995), and induction is believed to be regulated mainly by the PKACREB pathway (Douglass et al., 1994; Cole et al., 1995). We were unable to measure a significant induction of dynorphin mRNA after chronic amphetamine administration in either wild-type or mutant dorsolateral striatum with our drug treatment paradigm (data not shown). However, constitutive expression of dynorphin mRNA was reduced in the mutant striatum, particularly in the dorsolateral region, where expression was $\sim 30 \%$ of normal (Fig. 7). Expression in the dorsomedial region was also lower. These data suggest that constitutive dynorphin gene expression depends on PKA, which is reduced dramatically in the mutants. In view of the current literature, we speculate that the loss of PKAregulated expression of genes such as dynorphin might underlie the increased sensitization to amphetamine that is seen in the $\operatorname{RII} \beta$ mutant. 
A

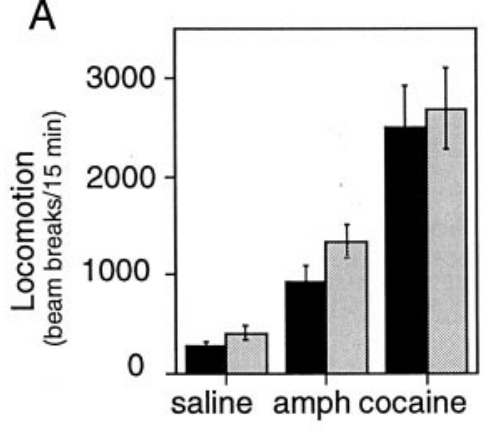

C

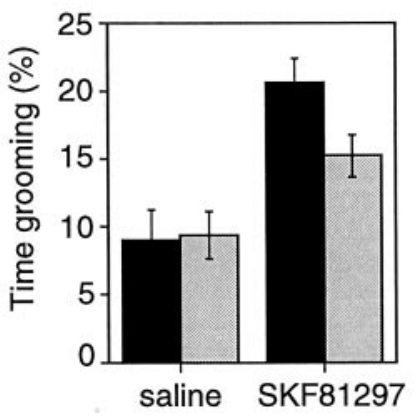

B
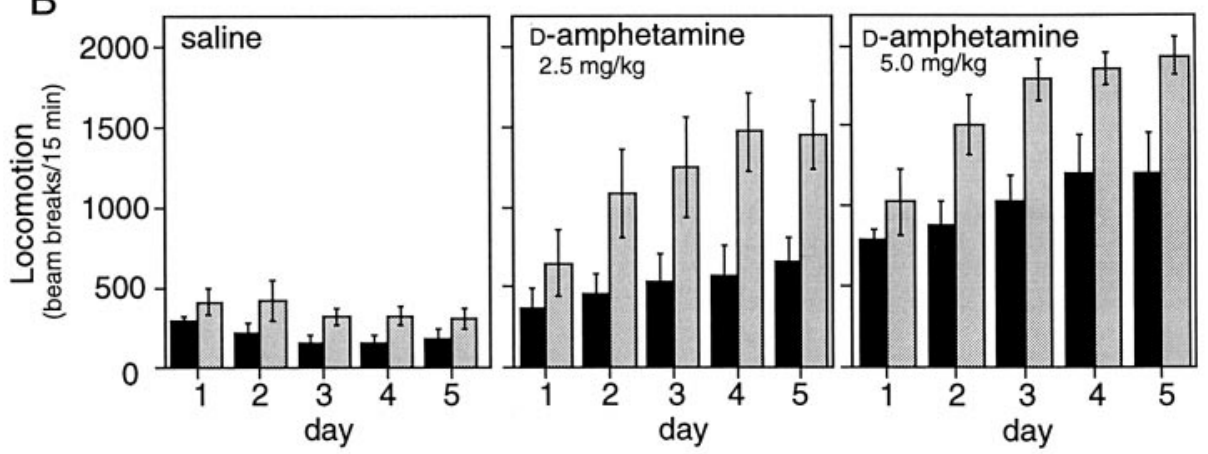

D

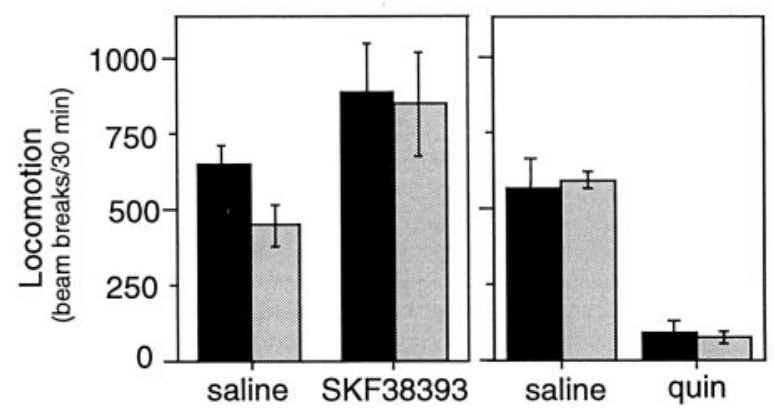

wt

RIIß ko

Figure 5. Response of RII $\beta$ mutants to dopaminergic agents. $A$, Acute locomotor responses. Wild-type (solid bars) and RII $\beta^{-/-}$(stippled bars) mice were treated with saline $(n=5 \mathrm{WT}$ and $5 \mathrm{KO})$, a $10 \mathrm{mg} / \mathrm{kg}$ dose of D-amphetamine $(a m p h ; n=5 \mathrm{WT}$ and $6 \mathrm{KO})$, or a $20 \mathrm{mg} / \mathrm{kg} \mathrm{dose}$ of cocaine $(n=6 \mathrm{WT}$ and $9 \mathrm{KO}$ ). Locomotor activity was determined in an open field by recording photobeam breaks. Error bars represent SEM. $B$, Enhanced sensitization to low-dose amphetamine. Wild-type (solid bars) and RII $\beta^{-1-}$ (stippled bars) mice were treated with saline $(n=5 \mathrm{WT}$ and $5 \mathrm{KO})$, a $2.5 \mathrm{mg} / \mathrm{kg}$ dose of D-amphetamine ( $n=5 \mathrm{WT}$ and $6 \mathrm{KO})$, or a $5 \mathrm{mg} / \mathrm{kg}$ dose of D-amphetamine $(n=6 \mathrm{WT}$ and $6 \mathrm{KO})$ for $5 \mathrm{~d}$, and locomotion was determined. Locomotor responses to three other doses were determined also (data not shown). When saline treatment was compared with 1.0, 2.5, 5.0, and $10 \mathrm{mg} / \mathrm{kg}$ doses of amphetamine, repeated measures ANOVA revealed a significant effect of genotype $\left(F_{(1,42)}=41.07 ; p<0.001\right)$. $C$, D1 agonist-induced grooming behavior. Wild-type (solid bars) and RII $\beta^{-1-}$ (stippled bars) mice were treated with saline $(n=8$ WT and $8 \mathrm{KO})$ or a $5.0 \mathrm{mg} / \mathrm{kg}$ dose of SKF81297 ( $n=18 \mathrm{WT}$ and $18 \mathrm{KO}$ ). Each mouse was observed for grooming and other activities; the percentage of time spent grooming is reported as mean \pm SEM. Grooming increased significantly with SKF81297 in both genotypes $(p<0.02)$, but mutants responded somewhat less than wild types $(p=0.05)$. $D$, Acute locomotor responses to D1 and D2 agonists. Wild-type (solid bars) and RII $\beta^{-/-}$(stippled bars) mice were treated with saline $(n=8 \mathrm{WT}$ and $11 \mathrm{KO})$, an $8.0 \mathrm{mg} / \mathrm{kg}$ dose of SKF38393 ( $n=5 \mathrm{WT}$ and $7 \mathrm{KO}$ ), or a $2.5 \mathrm{mg} / \mathrm{kg}$ dose of quinpirole (quin; $n=5 \mathrm{WT}$ and $5 \mathrm{KO}$ ), and locomotor responses were determined.

\begin{tabular}{|c|c|c|c|}
\hline Component & Wild-type & $\begin{array}{l}\mathrm{RII} \beta \mathrm{mu}- \\
\text { tant }\end{array}$ & Units \\
\hline Dopamine & $41.9 \pm 5.6$ & $38.5 \pm 3.4$ & $\mathrm{ng} / \mathrm{mg}$ protein \\
\hline \multicolumn{4}{|l|}{ D1 receptor $\left(\mathrm{B}_{\max }\right)$ : } \\
\hline DL & $50.4 \pm 7.6$ & $35.7 \pm 2.1$ & $\mathrm{fmol} / \mathrm{mg}$ tissue \\
\hline $\mathrm{DM}$ & $47.1 \pm 7.2$ & $39.9 \pm 3.4$ & $\mathrm{fmol} / \mathrm{mg}$ tissue \\
\hline VL & $45.0 \pm 6.7$ & $38.0 \pm 5.5$ & $\mathrm{fmol} / \mathrm{mg}$ tissue \\
\hline $\mathrm{VM}$ & $42.2 \pm 6.5$ & $38.4 \pm 3.9$ & $\mathrm{fmol} / \mathrm{mg}$ tissue \\
\hline \multicolumn{4}{|l|}{$\mathrm{D} 2$ receptor $\left(\mathrm{B}_{\max }\right)$ : } \\
\hline DL & $41.8 \pm 2.7$ & $36.5 \pm 3.2$ & $\mathrm{fmol} / \mathrm{mg}$ tissue \\
\hline $\mathrm{DM}$ & $32.9 \pm 1.8$ & $28.2 \pm 2.6$ & $\mathrm{fmol} / \mathrm{mg}$ tissue \\
\hline VL & $33.4 \pm 1.1$ & $32.9 \pm 2.3$ & $\mathrm{fmol} / \mathrm{mg}$ tissue \\
\hline VM & $27.8 \pm 1.1$ & $26.4 \pm 1.3$ & $\mathrm{fmol} / \mathrm{mg}$ tissue \\
\hline \multicolumn{4}{|l|}{ Dopamine transporter: } \\
\hline DA uptake & $0.81 \pm 0.19$ & $0.93 \pm .34$ & $\begin{array}{l}\mathrm{pmol} / \mathrm{min} \text { per } \mathrm{mg} \\
\text { of protein }\end{array}$ \\
\hline $\begin{array}{l}\text { Amphetamine inhibition } \\
\left(\mathrm{IC}_{50}\right)\end{array}$ & $0.16 \pm .07$ & $0.19 \pm .11$ & $\mu \mathrm{M}$ amphetamine \\
\hline
\end{tabular}

\section{DISCUSSION}

Regulatory subunits serve three recognized roles in the modulation of overall PKA activity in cells. First, they bind to and inhibit catalytic subunits when cAMP levels are low, and they respond to increases in cAMP by releasing the active $\mathrm{C}$ subunits. Second, the type II subunits (RII $\alpha$ and RII $\beta$ ) bind to a family of anchoring proteins (AKAPs) in the cell and consequently can specifically tether the PKA holoenzyme near potential substrates. Third, the interaction of $\mathrm{R}$ with $\mathrm{C}$ stabilizes both molecules against proteolysis, maintaining functional levels of PKA in the cell. Most cells express multiple $\mathrm{R}$ subunit isoforms; therefore, absence of a specific $\mathrm{R}$ subunit isoform might be expected to create a surplus of free $\mathrm{C}$ subunits, which could stabilize other $\mathrm{R}$ isoforms in the cell. This altered complement of $\mathrm{R}$ isoforms within the cell might change the subcellular localization of PKA or change its sensitivity to cAMP. If other $\mathrm{R}$ subunits within the cell are unable to compensate, a loss of $\mathrm{C}$ subunit is expected because of proteolysis.

Disruption of the RII $\beta$ subunit in mice leads to dramatic changes in the PKA system in tissues that express high levels of this subunit, such as adipose and brain. In white and brown adipose tissue the loss of RII $\beta$ is compensated for mainly by a concomitant increase in the $\mathrm{RI} \alpha$ subunit and assembly of a type I kinase with increased sensitivity to activation by cAMP (Cummings et al., 1996; Amieux et al., 1997). The physiological outcome of this change is brown adipose activation, leading to increased metabolic rate and a lean phenotype. In brain tissues we find much less compensation by RI and a greater loss of total 
A
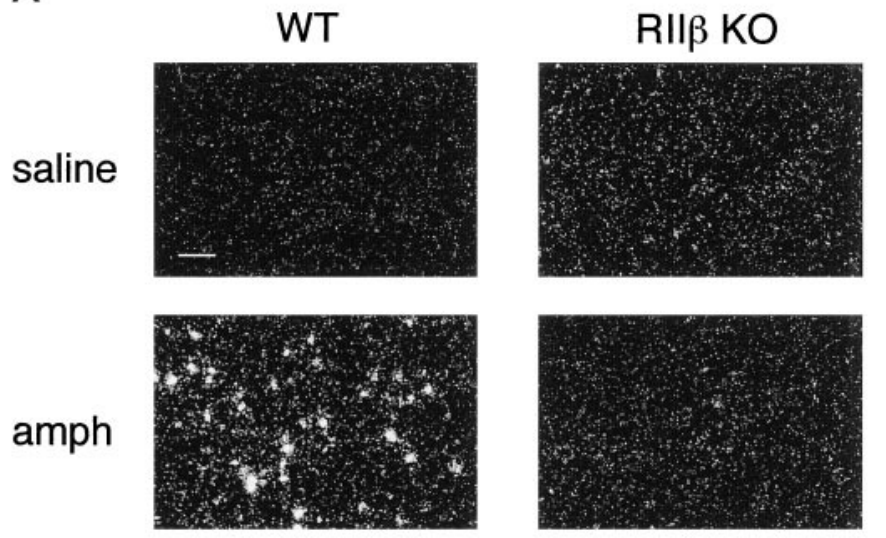

B
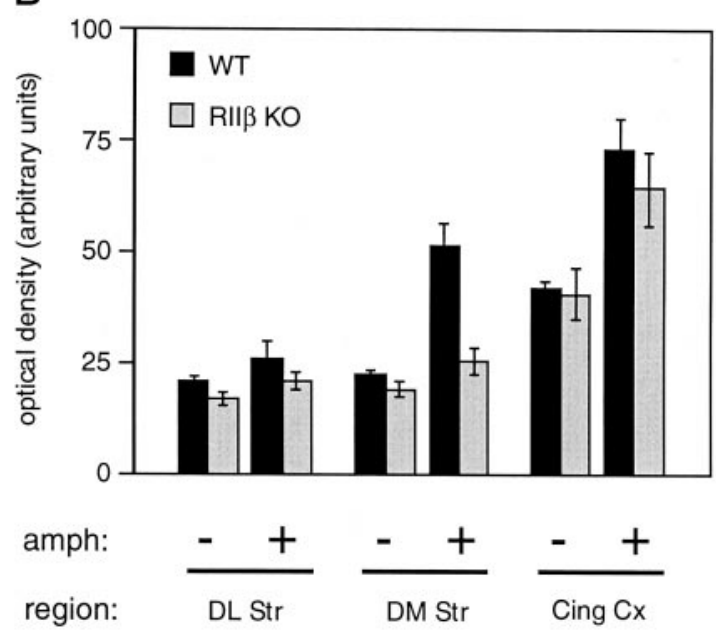

Figure 6. RII $\beta$ knock-out mice lack the induction of $c$-fos mRNA in the dorsomedial striatum by amphetamine. A, In situ hybridization for $c$-fos mRNA is shown as dark-field photomicrographs. Representative images from dorsomedial striatum demonstrate that $c$-fos mRNA expression is induced in wild-type mice (WT) $1 \mathrm{hr}$ after intraperitoneal injection of 10 $\mathrm{mg} / \mathrm{kg}$ D-amphetamine (bottom panels) but is not induced in RII $\beta^{-/-}$ mutants $(R I I \beta K O)$. Images from saline-treated animals of each genotype are shown also (top panels). Scale bar, $50 \mu \mathrm{m}$. B, Densitometry measurements from several forebrain regions of wild-type (solid bars) or RII $\beta^{-/-}$ (stippled bars) mice treated with saline $(-)$ or $10 \mathrm{mg} / \mathrm{kg}$ D-amphetamine $(+)$. RII $\beta^{-1-}$ mice do not induce $c$-fos in the dorsomedial (DM Str) region, as compared with wild-type mice $(p<0.001)$. Other regions shown are dorsolateral striatum (DL Str) and cingulate cortex (Cing Cx). Error bars represent SEM ( $n=3-6$ mice for each condition).

PKA activity because of $\mathrm{C}$ subunit degradation (see Fig. 1). The region of the brain that expresses the highest levels of $\operatorname{RII} \beta$, the striatum, suffers the greatest loss of total PKA activity, with only $\sim 25 \%$ of the kinase activity present in wild-type mice, whereas brain regions that express very little RII $\beta$, such as the cerebellum, maintain normal kinase levels as expected.

Within the medium spiny neurons of the striatum, RII $\beta$ protein is localized in dendritic and perikaryal regions (Ludvig et al., 1990; Glantz et al., 1992), suggesting possible roles in both immediate responses to dopaminergic transmission and longer term gene induction events associated with cAMP signaling. PKA anchoring proteins such as AKAP150 are coexpressed in striatal neurons and likely are essential for the subcellular distribution of RII $\beta$ (Glantz et al., 1992; Rubin, 1994; Faux and Scott, 1996). The functional significance of the coexpression has not been demon- strated directly for striatal neurons, but in hippocampal neurons the anchoring of PKA via AKAPs is important for AMPA/ kainate receptor modulation (Rosenmund et al., 1994). Despite the total loss of RII $\beta$ in our mutant mice, the levels of AKAP150 remain undisturbed in brain extracts (A. Sikorski and S. McKnight, unpublished data). Thus not only are the RII $\beta$ mutant mice PKA deficient, but they also have lost the major anchored form of PKA expressed in the striatum, and their phenotype may reflect a combination of the kinase deficiency and the absence of correct subcellular localization.

\section{Gene induction in striatal neurons is inhibited, but acute motor responses are normal}

The striatum is a major target for the neuromodulator, dopamine, and some of the actions of dopamine are thought to be mediated by changes in cAMP and the subsequent regulation of PKA activity. We examined whether dopaminergic signaling in the striatum was affected in RII $\beta$ mutant mice, leading to abnormalities in downstream effects on gene activation and behavior. Despite the complete loss of the major form of PKA in the striatum $(\mathrm{RII} \beta)$, the mutant mice continue to demonstrate normal acute locomotor responses to amphetamine and cocaine with rapid and robust increases in horizontal locomotor activity. These drugs act by increasing the levels of released dopamine in the synapse, stimulating both D1- and D2-like receptors to increase locomotor activity. In our studies, quinpirole, a D2/D3 agonist, acts to inhibit motor activity when given alone, and this inhibition was not affected by the loss of RII $\beta$. Administration of a D1R agonist caused a modest increase in motor activity, and the wild-type and RII $\beta$ mutant mice were again indistinguishable. This normal acute responsiveness of the RII $\beta$-deficient mice was surprising given previous studies in rats demonstrating the modulation of cocaine-induced locomotion by cAMP analogs infused into the nucleus accumbens (Miserendino and Nestler, 1995). Together, these studies suggest either that the low level of remaining PKA in the RII $\beta$ mutants is sufficient for coupling dopamine receptor occupancy to neuronal modulation or that other signal transduction pathways are primarily responsible for acute dopaminergic locomotor responses.

The RII $\beta$ mutant mice are deficient in their ability to modulate gene expression in both D1R and D2R neurons. The induction of c-fos mRNA in the dorsomedial striatum is nearly absent in the mutant mice (see Fig. 6), and the basal level of expression of dynorphin (a specific product of D1R neurons) is decreased in the mutant mice as well (see Fig. 7). These defects in gene expression are not limited to D1R neurons, because recently we have shown that the haloperidol-mediated induction of both $c-f o s$ and neurotensin mRNA is absent in the dorsolateral striatum of RII $\beta$ mutant mice (Adams et al., 1997). Haloperidol has D2R antagonist activity and would be expected to elicit an increase in cAMP and PKA activity in D2R-containing neurons by blocking the inhibitory effect of D2R on adenylyl cyclase. We postulate that neither D1R nor D2R neurons in RII $\beta$ mutant mice are fully functional in eliciting PKA-mediated gene induction because of their reduced PKA levels. Evidence for a graded response to cAMP levels is suggested by studies in Aplysia sensory neurons demonstrating that a robust activation of neurons is required to cause translocation of the $\mathrm{C}$ subunit into the nucleus and gene induction (Bacskai et al., 1993). Recent experiments performed with rat striatal cultures indicate that sustained phosphorylation by PKA of cAMP response element binding protein (CREB) or related transcription factors is essential for CRE-mediated gene 
WT

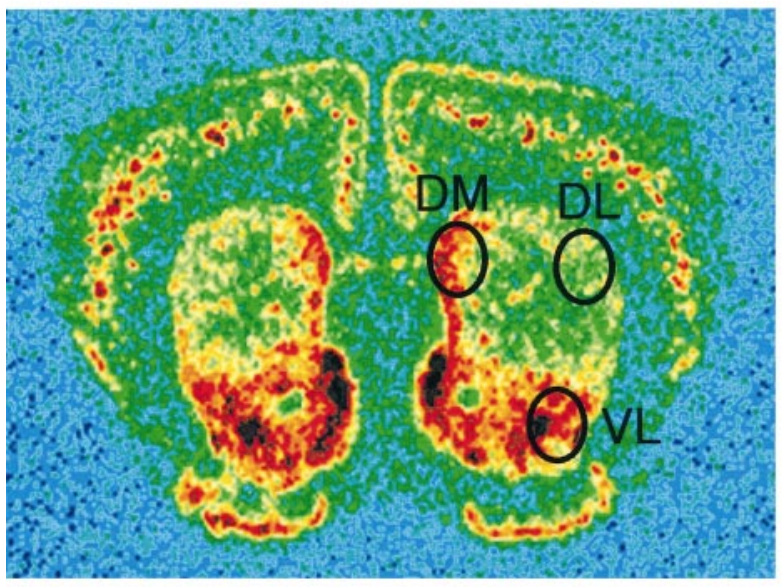

\section{$\mathrm{RII} \beta \mathrm{KO}$}

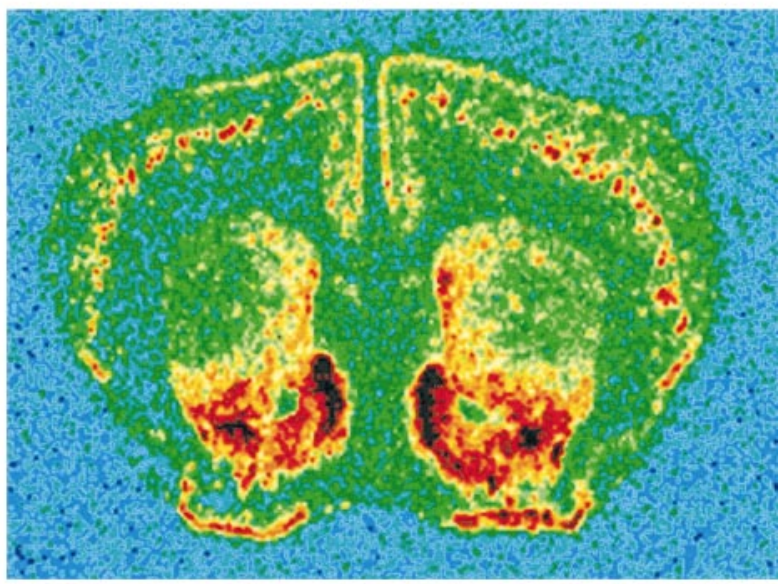

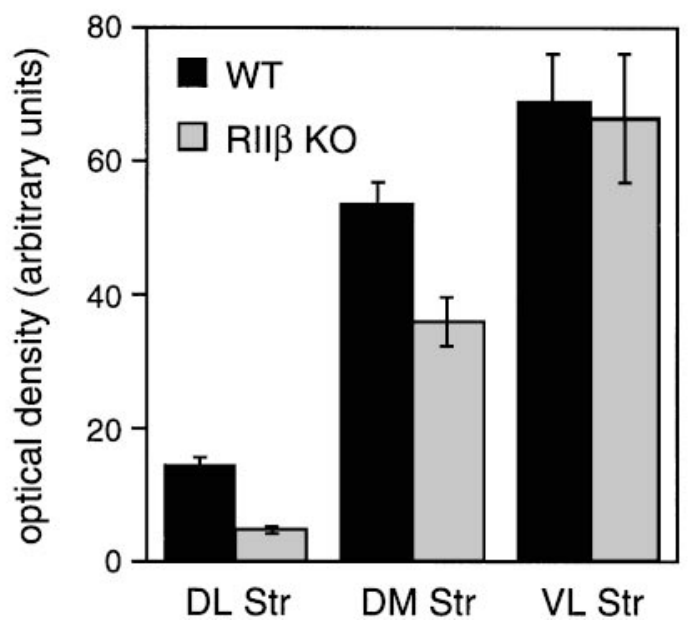

Figure 7. Dynorphin mRNA is reduced in RII $\beta$ knock-out mice. $A$, Dynorphin mRNA is expressed in a mainly normal pattern in RII $\beta^{-/-}$mice $(R I I \beta$ $K O$ ) but at reduced levels in the dorsolateral and dorsomedial regions. Wild-type (WT) brain is shown for comparison. Ovals indicate the regions sampled for the densitometric analysis shown in $B . B$, Quantitative densitometry of three regions of the striatum from wild-type (solid bars; $n=7)$ and RII $\beta^{-1-}$ mice (stippled bars; $n=7$ ) shows that no significant difference is observed in the ventrolateral striatum, but reductions are seen in the dorsolateral $(p<$ $0.001)$ and dorsomedial $(p<0.002)$ regions. Error bars represent SEM. DL, Dorsolateral; DM, dorsomedial; Str, striatum; VL, ventrolateral.

expression (Bito et al., 1996; Liu and Graybiel, 1996), consistent with our findings in the $\operatorname{RII} \beta$ mutants.

Sensitization to amphetamine and other psychostimulants requires protein synthesis and, very likely, changes in gene expression. Neuropeptides such as dynorphin may play an inhibitory role in sensitization (Heidbreder et al., 1995), and, as we show in Figure 7, dynorphin expression in the striatum is decreased in the RII $\beta$ mutants. Although the locomotor response to acute administration of high-dose amphetamine is very similar in mutant and control mice, chronic treatment with low-dose amphetamine resulted in exaggerated sensitization in the RII $\beta$ mutants (see Fig. 5 ). This altered responsiveness may result, at least in part, from the observed defects in basal and drug-induced gene expression.

\section{Complex locomotor behavior}

A model of striatal circuitry has been proposed previously (Albin et al., 1989; DeLong, 1990; Graybiel, 1990; Gerfen, 1992). In this model D1R-containing GABAergic striatal neurons primarily contribute to a direct pathway with output to the substantia nigra pars reticulata $(\mathrm{SNr})$. The GABAergic D2R neurons form an indirect pathway via the globus pallidus and subthalamic nucleus that ultimately results in a positive glutamatergic output at the SNr. The inhibitory (GABAergic) output of the direct pathway is integrated with the positive output from the indirect pathway by the SNr for which the output to the motor thalamus provides an inhibitory modulation of locomotor activity. Despite extensive studies the mechanisms by which dopamine modulates the output of striatal projection neurons remain unresolved, although it appears that dopamine affects the ability of these cells to respond to other inputs as opposed simply to evoking excitatory or inhibitory potentials itself (Bargas and Galarraga, 1995; Surmeier et al., 1995). Complex motor behaviors therefore may involve dopaminergic-mediated changes in the activity of the different striatal neurons, which then are deciphered by the $\mathrm{SNr}$ and integrated into a signal that is returned to the motor cortex. Although this is certainly an oversimplification of the neural pathways involved in modulating motor behavior, it provides a framework for analyzing phenotypic changes in locomotion in the $\mathrm{RII} \beta$-mutant mice.

What is the role of striatal PKA in the complex regulation of locomotor behavior? We observed no obvious impairment in the 
normal exploratory movement of RII $\beta$ mutant mice (see Fig. 4); however, when challenged on a rotarod apparatus, a more complicated locomotor task, the RII $\beta$ mutants displayed a severe deficit (see Fig. 3). This deficit could be attributable to a variety of factors. Cerebellar defects have been shown to affect performance in this task (Lalonde et al., 1995), but given the absence of any significant change in PKA activity in the RII $\beta$ knock-out cerebellum, this seemed unlikely. The paw print assessment (see Fig. 4) confirmed the absence of any detectable cerebellar abnormality. Earlier studies have indicated that striatal manipulations also can affect rotarod performance (Emerich et al., 1993), and dopamine metabolism has been found to be increased in the striatum during the performance of this task (Bertolucci et al., 1990). We postulate that the rotarod requires increased, temporally modulated activity of dopaminergic signaling and that PKA is important in the acquisition of this behavioral task. It is proposed that PKA-mediated gene expression events contribute to the "motor learning" that occurs during successive rotarod trials and that the deficit in gene expression in the RII $\beta$ mutants compromises such learning.

In conclusion, the RII $\beta$ mutant mice display discrete defects in motor behavior that correlate with a severe loss of striatal PKA activity and loss of PKA-mediated gene expression. Our observations support and extend the current thinking on the role of striatal dopamine in motor behavior and suggest that the $\operatorname{RII} \beta$ mutants should be particularly useful for further studies on the mechanisms of dopaminergic modulation of gene expression and behavior.

\section{REFERENCES}

Accili D, Fishburn CS, Drago J, Steiner H, Lachowicz JE, Park BH, Gauda EB, Lee EJ, Cool MH, Sibley DR, Gerfen CR, Westphal H, Fuchs S (1996) A targeted mutation of the D3 dopamine receptor gene is associated with hyperactivity in mice. Proc Natl Acad Sci USA 93:1945-1949.

Adams MR, Brandon EP, Chartoff EH, Idzerda RL, Dorsa DM, McKnight GS (1997) Loss of haloperidol-induced gene expression and catalepsy in protein kinase A-deficient mice. Proc Natl Acad Sci USA 94:12157-12161.

Albin RL, Young AB, Penney JB (1989) The functional anatomy of basal ganglia disorders. Trends Neurosci 12:366-375.

Amieux PS, Cummings DE, Motamed K, Brandon EP, Wailes LA, Le K, Idzerda RL, McKnight GS (1997) Compensatory regulation of RI $\alpha$ protein levels in protein kinase A mutant mice. J Biol Chem 272:3993-3998.

Angulo JA, McEwen BS (1994) Molecular aspects of neuropeptide regulation and function in the corpus striatum and nucleus accumbens. Brain Res Rev 19:1-28.

Bacskai BJ, Hochner B, Mahaut SM, Adams SR, Kaang BK, Kandel ER, Tsien RY (1993) Spatially resolved dynamics of cAMP and protein kinase A subunits in Aplysia sensory neurons. Science 260:222-226.

Baik JH, Picetti R, Saiardi A, Thiriet G, Dierich A, Depaulis A, Le Meur M, Borrelli E (1995) Parkinsonian-like locomotor impairment in mice lacking dopamine D2 receptors. Nature 377:424-428.

Bargas J, Galarraga E (1995) Firing response modulation in neostriatal projection neurons by cholinergic and dopaminergic agonists. In: Molecular and cellular mechanisms of neostriatal function (Ariano MA, Surmeier DJ, eds), pp 183-191. Austin, TX: Landes.

Bertolucci DM, Serrano A, Scatton B (1990) Differential effects of forced locomotion, tail-pinch, immobilization, and methyl-betacarboline carboxylate on extracellular 3,4-dihydroxyphenylacetic acid levels in the rat striatum, nucleus accumbens, and prefrontal cortex: an in vivo voltammetric study. J Neurochem 55:1208-1215.

Bito H, Deisseroth K, Tsien RW (1996) CREB phosphorylation and dephosphorylation: a $\mathrm{Ca}^{2+}$ - and stimulus duration-dependent switch for hippocampal gene expression. Cell 87:1203-1214.

Bouthenet ML, Souil E, Martres MP, Sokoloff P, Giros B, Schwartz JC (1991) Localization of dopamine D3 receptor mRNA in the rat brain using in situ hybridization histochemistry: comparison with dopamine D2 receptor mRNA. Brain Res 564:203-219.

Brandon EP, Gerhold KA, Qi M, McKnight GS, Idzerda RL (1995a) Derivation of novel embryonic stem cell lines and targeting of cyclic AMP-dependent protein kinase genes. Recent Prog Horm Res 50:403-408.

Brandon EP, Zhuo M, Huang YY, Qi M, Gerhold KA, Burton KA, Kandel ER, McKnight GS, Idzerda RL (1995b) Hippocampal longterm depression and depotentiation are defective in mice carrying a targeted disruption of the gene encoding the RI $\beta$ subunit of cAMPdependent protein kinase. Proc Natl Acad Sci USA 92:8851-8855.

Cadd G, McKnight GS (1989) Distinct patterns of cAMP-dependent protein kinase gene expression in mouse brain. Neuron 3:71-79.

Cadd GG, Uhler MD, McKnight GS (1990) Holoenzymes of cAMPdependent protein kinase containing the neural form of type I regulatory subunit have an increased sensitivity to cyclic nucleotides. J Biol Chem 265:19502-19506.

Camp DM, Browman KE, Robinson TE (1994) The effects of methamphetamine and cocaine on motor behavior and extracellular dopamine in the ventral striatum of Lewis versus Fischer 344 rats. Brain Res 668:180-193.

Capecchi MR (1989) Altering the genome by homologous recombination. Science 244:1288-1292.

Clegg CH, Correll LA, Cadd GG, McKnight GS (1987) Inhibition of intracellular cAMP-dependent protein kinase using mutant genes of the regulatory type I subunit. J Biol Chem 262:13111-13119.

Cole RL, Konradi C, Douglass J, Hyman SE (1995) Neuronal adaptation to amphetamine and dopamine: molecular mechanisms of prodynorphin gene regulation in rat striatum. Neuron 14:813-823.

Creese I, Iversen SD (1975) The pharmacological and anatomical substrates of the amphetamine response in the rat. Brain Res 83:419-436.

Cummings DE, Brandon EP, Planas JA, Motamed K, Idzerda RL, McKnight GS (1996) Genetically lean mice result from targeted disruption of the RII $\beta$ subunit of protein kinase A. Nature 382:622-626.

DeLong M (1990) Primate models of movement disorders of basal ganglia origin. Trends Neurosci 13:281-285.

Douglass J, McKinzie AA, Pollock KM (1994) Identification of multiple DNA elements regulating basal and protein kinase A-induced transcriptional expression of the rat prodynorphin gene. Mol Endocrinol 8:333-344.

Drago J, Gerfen CR, Lachowicz JE, Steiner H, Hollon TR, Love PE, Ooi GT, Grinberg A, Lee EJ, Huang SP, Bartlett PF, Jose PA, Sibley DR, Westphal H (1994) Altered striatal function in a mutant mouse lacking D1A dopamine receptors. Proc Natl Acad Sci USA 91:12564-12568.

Dunham NW, Miya TS (1957) A note on a simple apparatus for detecting neurological deficit in rats and mice. J Am Pharm Assoc 46:208-209.

Emerich DF, McDermott PE, Krueger PM, Frydel B, Sanberg PR, Winn SR (1993) Polymer-encapsulated PC12 cells promote recovery of motor function in aged rats. Exp Neurol 122:37-47.

Faux MC, Scott JD (1996) Molecular glue: kinase anchoring and scaffold proteins. Cell 85:9-12.

Gage FH, Dunnett SB, Stenevi U, Bjorklund A (1983) Aged rats: recovery of motor impairments by intrastriatal nigral grafts. Science 221:966-969.

Gerfen CR (1992) The neostriatal mosaic: multiple levels of compartmental organization. Trends Neurosci 15:133-139.

Gerfen CR, Engber TM, Mahan LC, Susel Z, Chase TN, Monsma FJJ, Sibley DR (1990) D1 and D2 dopamine receptor-regulated gene expression of striatonigral and striatopallidal neurons. Science 250:1429-1432.

Giros B, Jaber M, Jones SR, Wightman RM, Caron MG (1996) Hyperlocomotion and indifference to cocaine and amphetamine in mice lacking the dopamine transporter. Nature 379:606-612.

Glantz SB, Amat JA, Rubin CS (1992) cAMP signaling in neurons: patterns of neuronal expression and intracellular localization for a novel protein, AKAP 150, that anchors the regulatory subunit of cAMP-dependent protein kinase II beta. Mol Biol Cell 3:1215-1228.

Goelet P, Castellucci VF, Schacher S, Kandel ER (1986) The long and the short of long-term memory-a molecular framework. Nature 322:419-422.

Grady S, Marks MJ, Wonnacott S, Collins AC (1992) Characterization of nicotine receptor-mediated $\left[{ }^{3} \mathrm{H}\right]$-dopamine release from synaptosomes prepared from mouse striatum. J Neurochem 59:848-856. 
Graybiel AM (1990) Neurotransmitters and neuromodulators in the basal ganglia. Trends Neurosci 13:244-254.

Greif GJ, Lin YJ, Liu JC, Freedman JE (1995) Dopamine-modulated potassium channels on rat striatal neurons: specific activation and cellular expression. J Neurosci 15:4533-4544.

Groves PM, Rebec GV (1976) Biochemistry and behavior: some central actions of amphetamine and antipsychotic drugs. Annu Rev Psychol 27:91-127.

Heidbreder CA, Babovic-Vuksanovic D, Shoaib M, Shippenberg TS (1995) Development of behavioral sensitization to cocaine: influence of kappa opioid receptor agonists. J Pharmacol Exp Ther 275:150-163.

Hersch SM, Ciliax BJ, Gutekunst CA, Rees HD, Heilman CJ, Yung KK, Bolam JP, Ince E, Yi H, Levey AI (1995) Electron microscopic analysis of D1 and D2 dopamine receptor proteins in the dorsal striatum and their synaptic relationships with motor corticostriatal afferents. J Neurosci 15:5222-5237.

Jaber M, Cador M, Dumartin B, Normand E, Stinus L, Bloch B (1995) Acute and chronic amphetamine treatments differently regulate neuropeptide messenger RNA levels and Fos immunoreactivity in rat striatal neurons. Neuroscience 65:1041-1050.

Jahnsen T, Hedin L, Lohmann SM, Walter U, Richards JS (1986) The neural type II regulatory subunit of cAMP-dependent protein kinase is present and regulated by hormones in the rat ovary. J Biol Chem 261:6637-6639.

Kalivas PW, Stewart J (1991) Dopamine transmission in the initiation and expression of drug- and stress-induced sensitization of motor activity. Brain Res Rev 16:223-244.

Karler R, Finnegan KT, Calder LD (1993) Blockade of behavioral sensitization to cocaine and amphetamine by inhibitors of protein synthesis. Brain Res 603:19-24.

Koob GF, Stinus L, Le Moal M (1981) Hyperactivity and hypoactivity produced by lesions to the mesolimbic dopamine system. Behav Brain Res 3:341-359.

Lalonde R, Bensoula AN, Filali M (1995) Rotarod sensorimotor learning in cerebellar mutant mice. Neurosci Res 22:423-426.

Liebmann JE, Matsumoto AM (1990) Acute selective withdrawal of testosterone negative feedback increases luteinizing hormone secretion without altering hypothalamic catecholaminergic neuronal activity. Endocrinology 126:555-564.

Liu FC, Graybiel AM (1996) Spatiotemporal dynamics of CREB phosphorylation: transient versus sustained phosphorylation in the developing striatum. Neuron 17:1133-1144.

Ludvig N, Ribak CE, Scott JD, Rubin CS (1990) Immunocytochemical localization of the neural-specific regulatory subunit of the type II cyclic AMP-dependent protein kinase to postsynaptic structures in the rat brain. Brain Res 520:90-102.

McMillen BA (1983) CNS stimulants: two distinct mechanisms of action for amphetamine-like drugs. Trends Pharmacol Sci 4:429-432.

Miserendino MJ, Nestler EJ (1995) Behavioral sensitization to cocaine: modulation by the cyclic AMP system in the nucleus accumbens. Brain Res 674:299-306.

Mosley B, Beckmann MP, March CJ, Idzerda RL, Gimpel SD, VandenBos T, Friend D, Alpert A, Anderson D, Jackson J, Wignall JM, Smith C, Gallis B, Sims JE, Urdal D, Widmer MB, Cosman D, Park LS (1989) The murine interleukin-4 receptor: molecular cloning and characterization of secreted and membrane bound forms. Cell 59:335-348.

Oyen O, Eskild W, Beebe SJ, Hansson V, Jahnsen T (1988) Biphasic response to $3^{\prime}, 5^{\prime}$-cyclic adenosine monophosphate (cAMP) at the messenger ribonucleic acid level for a regulatory subunit of cAMPdependent protein kinase. Mol Endocrinol 2:1070-1076.

Pauly JR, Robinson SF, Collins AC (1993) Chronic corticosterone administration enhances behavioral sensitization to amphetamine in mice. Brain Res 620:195-202.

Picetti R, Saiardi A, Samad TA, Bozzi Y, Baik J-H, Borrelli E (1997) Dopamine D2 receptors in signal transduction and behavior. Crit Rev Neurobiol 11:121-142.

Robinson TE, Becker JB (1986) Enduring changes in brain and behavior produced by chronic amphetamine administration: a review and eval- uation of animal models of amphetamine psychosis. Brain Res 396:157-198.

Rosenmund C, Carr DW, Bergeson SE, Nilaver G, Scott JD, Westbrook GL (1994) Anchoring of protein kinase A is required for modulation of AMPA/kainate receptors on hippocampal neurons. Nature 368:853-856.

Rubin CS (1994) A kinase anchor proteins and the intracellular targeting of signals carried by cyclic AMP. Biochim Biophys Acta 1224:467-479.

Rubinstein M, Phillips TJ, Bunzow JR, Falzone TL, Dziewczapolski G, Zhang G, Fang Y, Larson JL, McDougall JA, Chester JA, Saez C, Pugsley TA, Gershanik O, Low MJ, Grandy DK (1997) Mice lacking dopamine D4 receptors are supersensitive to ethanol, cocaine, and methamphetamine. Cell 90:991-1001.

Sassone-Corsi P, Visvader J, Ferland L, Mellon PL, Verma IM (1988) Induction of proto-oncogene fos transcription through the adenylate cyclase pathway: characterization of a cAMP-responsive element. Genes Dev 2:1529-1538.

Sheng M, McFadden G, Greenberg ME (1990) Membrane depolarization and calcium induce $c$-fos transcription via phosphorylation of transcription factor CREB. Neuron 4:571-582.

Steiner H, Gerfen CR (1993) Cocaine-induced $c$-fos messenger RNA is inversely related to dynorphin expression in striatum. J Neurosci 13:5066-5081.

Stoof JC, Kebabian JW (1981) Opposing roles for D1 and D2 dopamine receptors in efflux of cyclic AMP from rat neostriatum. Nature 294:366-368.

Sulzer D, Chen TK, Lau YY, Kristensen H, Rayport S, Ewing A (1995) Amphetamine redistributes dopamine from synaptic vesicles to the cytosol and promotes reverse transport. J Neurosci 15:4102-4108.

Surmeier DJ, Cantrell AR, Carter-Russell H (1995) Dopaminergic and cholinergic modulation of calcium conductances in neostriatal neurons. In: Molecular and cellular mechanisms of neostriatal function (Ariano MA, Surmeier DJ, eds), pp 193-215. Austin, TX: Landes.

Surmeier DJ, Song WJ, Yan Z (1996) Coordinated expression of dopamine receptors in neostriatal medium spiny neurons. J Neurosci 16:6579-6591.

Thompson LA, Matsumoto RR, Hohmann AG, Walker JM (1990) Striatonigral prodynorphin: a model system for understanding opioid peptide function. Ann NY Acad Sci 579:192-203.

Ujike H, Onoue T, Akiyama K, Hamamura T, Otsuki S (1989) Effects of selective D1 and D2 dopamine antagonists on development of methamphetamine-induced behavioral sensitization. Psychopharmacology (Berl) 98:89-92.

Vezina P, Stewart J (1989) The effect of dopamine receptor blockade on the development of sensitization to the locomotor activating effects of amphetamine and morphine. Brain Res 499:108-120.

Walsh SL, Wagner GC (1992) Motor impairments after methamphetamine-induced neurotoxicity in the rat. J Pharmacol Exp Ther 263:617-626.

Wang JQ, Smith AJ, McGinty JF (1995) A single injection of amphetamine or methamphetamine induces dynamic alterations in $c$-fos, zif/ 268 , and preprodynorphin messenger RNA expression in rat forebrain. Neuroscience 68:83-95.

Ward RP, Dorsa DM (1996) Colocalization of serotonin receptor subtypes 5-HT2A, 5-HT2C, and 5-HT6 with neuropeptides in rat striatum. J Comp Neurol 370:405-414.

Xu M, Hu XT, Cooper DC, Moratalla R, Graybiel AM, White FJ, Tonegawa S (1994a) Elimination of cocaine-induced hyperactivity and dopamine-mediated neurophysiological effects in dopamine D1 receptor mutant mice. Cell 79:945-955.

$\mathrm{Xu}$ M, Moratalla R, Gold LH, Hiroi N, Koob GF, Graybiel AM, Tonegawa S (1994b) Dopamine D1 receptor mutant mice are deficient in striatal expression of dynorphin and in dopamine-mediated behavioral responses. Cell 79:729-742.

Zhou QY, Palmiter RD (1995) Dopamine-deficient mice are severely hypoactive, adipsic, and aphagic. Cell 83:1197-1209. 